\title{
Stenotrophomonas dokdonensis sp. nov., isolated from soil
}

\author{
Jung-Hoon Yoon, So-Jung Kang, Hyun Woo Oh and Tae-Kwang Oh \\ Korea Research Institute of Bioscience and Biotechnology (KRIBB), PO Box 115, Yusong, \\ Taejon, Korea
}

Correspondence

Jung-Hoon Yoon

jhyoon@kribb.re.kr

\begin{abstract}
A Gram-negative, rod-shaped, Stenotrophomonas-like bacterial strain, DS-16 ${ }^{\top}$, was isolated from soil from Dokdo, Korea, and subjected to a polyphasic taxonomic study. Strain DS-16 ${ }^{\top}$ grew optimally at $\mathrm{pH} 6 \cdot 0-7 \cdot 0$ and $30^{\circ} \mathrm{C}$ in the presence of $0.5 \%(\mathrm{w} / \mathrm{v}) \mathrm{NaCl}$. It contained $\mathrm{Q}-8$ as the predominant ubiquinone and iso- $\mathrm{C}_{16: 0}$, iso- $\mathrm{C}_{15: 0}$ and iso- $\mathrm{C}_{17: 1} \omega 9 \mathrm{c}$ as the major fatty acids. The DNA G $+\mathrm{C}$ content was $65 \cdot 1 \mathrm{~mol} \%$. Phylogenetic analyses based on $16 \mathrm{~S}$ rRNA gene sequences showed that strain DS-16 ${ }^{\top}$ joined the cluster comprising Stenotrophomonas species. The levels of $16 \mathrm{~S}$ rRNA gene sequence similarity between strain DS-16 ${ }^{\top}$ and the type strains of Stenotrophomonas species ranged from 95.5 to $97.5 \%$. DNA-DNA relatedness data and differential phenotypic properties, together with the phylogenetic distinctiveness of strain DS-16 ${ }^{\top}$, demonstrated that this novel strain differs from Stenotrophomonas species with validly published names. On the basis of phenotypic, phylogenetic and genetic data, strain DS-16 ${ }^{\top}$ (=KCTC $12543^{\top}=$ CIP $108839^{\top}$ ) should be classified in the genus Stenotrophomonas as a member of a novel species, for which the name Stenotrophomonas dokdonensis sp. nov. is proposed.
\end{abstract}

The genus Stenotrophomonas was proposed through the reclassification of Xanthomonas maltophila as Stenotrophomonas maltophila (Palleroni \& Bradbury, 1993). At the time of writing, the genus comprises four species with validly published names: Stenotrophomonas maltophila (Palleroni \& Bradbury, 1993), Stenotrophomonas nitritireducens (Finkmann et al., 2000), Stenotrophomonas acidaminiphila (Assih et al., 2002) and Stenotrophomonas rhizophila (Wolf et al., 2002). In this study, we report on the taxonomic characterization of a Stenotrophomonas-like bacterial strain, DS-16 ${ }^{\mathrm{T}}$, which was isolated from a soil sample from Dokdo island $\left(37^{\circ} 14^{\prime} 12^{\prime \prime} \mathrm{N}, 131^{\circ} 52^{\prime} 07^{\prime \prime} \mathrm{E}\right)$, Korea.

Strain DS- $16^{\mathrm{T}}$ was isolated by means of the standard dilution plating technique at $25^{\circ} \mathrm{C}$ on $10 \times$ diluted nutrient agar (Difco). The type strains of four Stenotrophomonas species were used as reference strains: S. maltophila KCTC $1773^{\mathrm{T}}$, S. nitritireducens KCTC $12168^{\mathrm{T}}$, S. acidaminiphila KCTC $12167^{\mathrm{T}}$ and S. rhizophila KCTC $12169^{\mathrm{T}}$ were obtained from the Korean Collection for Type Cultures, Taejon, Korea. The morphological, physiological and biochemical characteristics of strain DS-16 ${ }^{\mathrm{T}}$ were investigated using routine cultivation on trypticase soy agar (TSA; Difco) at $30{ }^{\circ} \mathrm{C}$. The cell morphology was examined by using light

The GenBank/EMBL/DDBJ accession number for the 16S rRNA gene sequence of strain DS-16 ${ }^{\top}$ is DQ178977.

Phenotypic characteristics of Stenotrophomonas dokdonensis sp. nov. and the type strains of other Stenotrophomonas species are provided in a supplementary table available in IJSEM Online. microscopy (E600; Nikon) and transmission electron microscopy. The presence of flagella was determined with a transmission electron microscope (CM-20; Philips), using cells from exponentially growing cultures. For transmission electron microscopic observation, the cells were negatively stained with $1 \%(\mathrm{w} / \mathrm{v})$ phosphotungstic acid and the grids were air-dried. The Gram reaction was determined using the bioMérieux Gram stain kit according to the manufacturer's instructions. Growth at various temperatures $\left(4-45^{\circ} \mathrm{C}\right)$ was measured on TSA. Growth in the absence of $\mathrm{NaCl}$ and at various $\mathrm{NaCl}$ concentrations $[0.5 \%(\mathrm{w} / \mathrm{v})$ and $1 \cdot 0-5 \cdot 0 \%$ $(\mathrm{w} / \mathrm{v})$ using $1.0 \%$ increments] was investigated using trypticase soy broth prepared according to the formula of the Difco medium except that no $\mathrm{NaCl}$ was included. The $\mathrm{pH}$ range for growth was determined in nutrient broth (Difco) adjusted to various $\mathrm{pH}$ values $(\mathrm{pH} 4 \cdot 5-10 \cdot 5$, using increments of $0.5 \mathrm{pH}$ units) prior to sterilization by the addition of $\mathrm{HCl}$ or $\mathrm{Na}_{2} \mathrm{CO}_{3}$. Growth under anaerobic conditions was determined after incubation in an anabic chamber on TSA and on TSA supplemented with nitrate, both of which had been prepared anaerobically using nitrogen. Catalase and oxidase activities and the hydrolysis of casein, gelatin, hypoxanthine, starch, Tweens 20, 40, 60 and 80, tyrosine, urea and xanthine were investigated as described by Cowan \& Steel (1965). Hydrolysis of aesculin and nitrate reduction were studied as described previously (Lanyi, 1987). Sensitivity to antibiotics was tested on TSA plates using antibiotic discs containing the following concentrations: polymyxin $\mathrm{B}, 100 \mathrm{U}$; streptomycin, $50 \mu \mathrm{g}$; penicillin G, $20 \mathrm{U}$; chloramphenicol, $100 \mu \mathrm{g}$; ampicillin, $10 \mu \mathrm{g}$; 
Table 1. Differential phenotypic characteristics of $S$. dokdonensis sp. nov. and Stenotrophomonas species

Species: 1, S. dokdonensis sp. nov.; 2, S. maltophila, data from Palleroni (1984), Palleroni \& Bradbury (1993), Finkmann et al. (2000), Wolf et al. (2002) and this study; 3, S. nitritireducens, data from Finkmann et al. (2000), Assih et al. (2002), Wolf et al. (2002) and this study; 4, S. acidaminiphila, data from Assih et al. (2002) and this study; 5, S. rhizophila, data from Wolf et al. (2002) and this study. Symbols: +, positive reaction; -, negative reaction; ND, not determined or not described; V, variable reaction; W, weakly positive. Data for the type strain are shown in parentheses. All species are straight or slightly curved rods, positive for assimilation (data for type strains of $S$. maltophila and S. nitritireducens) of $\mathrm{N}$-acetylglucosamine, and negative for assimilation (data for type strains of S. maltophila, S. nitritireducens and S. rhizophila) of arabinose, mannitol, gluconate, caprate, adipate and phenylacetate.

\begin{tabular}{|c|c|c|c|c|c|}
\hline Characteristic & 1 & 2 & 3 & 4 & 5 \\
\hline Oxidase & + & $+^{*}$ & $(-)$ & + & $(+) \dagger$ \\
\hline \multicolumn{6}{|l|}{ Growth at: } \\
\hline $4{ }^{\circ} \mathrm{C}$ & - & - & $(-)$ & - & + \\
\hline $37^{\circ} \mathrm{C}$ & + & + & $\mathrm{V}(+)$ & + & + \\
\hline $41^{\circ} \mathrm{C}$ & - & - & $(-) \dagger$ & + & - \\
\hline Growth in the presence of $5 \%(\mathrm{w} / \mathrm{v}) \mathrm{NaCl}$ & + & + & $(-) \dagger$ & $(-) \dagger$ & - \\
\hline Nitrate reduction & + & + & - & + & + \\
\hline \multicolumn{6}{|l|}{ Hydrolysis of: } \\
\hline Aesculin & + & $(+)$ & - & + & + \\
\hline Casein & - & $(+) \dagger$ & $(-) \dagger$ & $(\mathrm{w}) \dagger$ & $(+) \dagger$ \\
\hline Gelatin & + & + & $(-) \dagger$ & $(-) \dagger$ & $(+) \dagger$ \\
\hline Starch & - & $(\mathrm{w}) \dagger$ & $(-) \dagger$ & $(-) \dagger$ & $(-) \dagger$ \\
\hline Tween 80 & + & + & $\mathrm{V}$ & + & $(+) \dagger$ \\
\hline \multicolumn{6}{|l|}{ Assimilation of: } \\
\hline Cellobiose & + & $(+) \dagger$ & $(-) \dagger$ & $(-) \dagger$ & $(+) \dagger$ \\
\hline Gentiobiose & + & $(+) \dagger$ & $(-) \dagger$ & $(-) \dagger$ & $(+) \dagger$ \\
\hline Glucose & + & + & $(-) \dagger$ & $(+)$ & + \\
\hline Lactose & - & $(-) \dagger$ & $(-) \dagger$ & $(-) \dagger$ & $(+) \dagger$ \\
\hline D-Lyxose & + & $(-) \dagger$ & $(-) \dagger$ & $(-) \dagger$ & $(-) \dagger$ \\
\hline Mannose & + & + & $(-)$ & $(+)$ & + \\
\hline Maltose & + & + & $(-)$ & $(+)$ & + \\
\hline Melibiose & - & $(-) \dagger$ & $(-) \dagger$ & $(-) \dagger$ & $(+) \dagger$ \\
\hline Sucrose & - & $(+) \dagger$ & $(-) \dagger$ & $(-) \dagger$ & $(+) \dagger$ \\
\hline Trehalose & + & $(+) \dagger$ & $(-) \dagger$ & $(-) \dagger$ & $(+) \dagger$ \\
\hline D-Turanose & - & $(+) \dagger$ & $(-) \dagger$ & $(-) \dagger$ & $(+) \dagger$ \\
\hline D-Xylose & + & $(-) \dagger$ & $(+) \dagger$ & $(-) \dagger$ & $(+) \dagger$ \\
\hline Amygdalin & + & $(+) \dagger$ & $(-) \dagger$ & $(-) \dagger$ & $(+) \dagger$ \\
\hline Arbutin & - & $(+) \dagger$ & $(-) \dagger$ & $(-) \dagger$ & $(+) \dagger$ \\
\hline Aesculin & + & $(+) \dagger$ & $(-) \dagger$ & $(-) \dagger$ & $(+) \dagger$ \\
\hline Glycogen & + & $(-) \dagger$ & $(-) \dagger$ & $(-) \dagger$ & $(-) \dagger$ \\
\hline Salicin & - & $(+) \dagger$ & $(-) \dagger$ & $(-) \dagger$ & $(+) \dagger$ \\
\hline Starch & + & $(\mathrm{w}) \dagger$ & $(-) \dagger$ & $(-) \dagger$ & $(-) \dagger$ \\
\hline Malate & - & + & $(-) \dagger$ & $(-)$ & $(+) \dagger$ \\
\hline Citrate & - & + & $(+) \dagger$ & $(-)$ & + \\
\hline \multicolumn{6}{|l|}{ API ZYM } \\
\hline Leucine arylamidase & + & $(-) \dagger$ & $(-) \dagger$ & $(-) \dagger$ & $(-) \dagger$ \\
\hline Naphthol-AS-BI-phosphohydrolase & + & $(\mathrm{w}) \dagger$ & $(-) \dagger$ & $(-) \dagger$ & $(+) \dagger$ \\
\hline$\alpha$-Glucosidase & - & $(-) \dagger$ & $(-) \dagger$ & $(\mathrm{W}) \dagger$ & $(-) \dagger$ \\
\hline$N$-acetyl- $\beta$-glucosaminidase & + & $(-) \dagger$ & $(+) \dagger$ & $(+) \dagger$ & $(-) \dagger$ \\
\hline \multicolumn{6}{|l|}{ Susceptibility to: } \\
\hline Ampicillin & - & $(-)$ & $\mathrm{V}(-)$ & $(-) \dagger$ & $(-) \dagger$ \\
\hline Gentamicin & + & $(-)$ & $\mathrm{V}(-)$ & + & - \\
\hline Kanamycin & + & $-\ddagger$ & + & $(+) \dagger$ & + \\
\hline Neomycin & + & $(-)$ & $\mathrm{V}(-)$ & $(+) \dagger$ & $(+) \dagger$ \\
\hline Novobiocin & + & - & - & $(-) \dagger$ & $(-) \dagger$ \\
\hline Penicillin G & + & $(-)$ & $\mathrm{V}(-)$ & $(-) \dagger$ & $(-) \dagger$ \\
\hline
\end{tabular}


Table 1. cont.

\begin{tabular}{|cccccc|}
\hline Characteristic & $\mathbf{1}$ & $\mathbf{2}$ & $\mathbf{3}$ & $\mathbf{4}$ & $(+) \dagger$ \\
\hline Streptomycin & + & $(-)$ & + & $(+) \dagger$ \\
Tetracycline & + & $-\ddagger$ & - & $(-) \dagger$ & $(66 \cdot 1) \dagger$ \\
DNA G+C content $(\mathrm{mol} \%)$ & $65 \cdot 1$ & $(66 \cdot 7) \dagger$ & $(69 \cdot 4-67 \cdot 4$ & $(67 \cdot 9) \dagger$ \\
\hline
\end{tabular}

${ }^{\star}$ Positive for the majority of strains.

$\dagger$ Data from this study for the type strain.

$\ddagger$ Data from Palleroni \& Bradbury (1993); opposite results were obtained by Finkmann et al. (2000) for the type strain.

cephalothin, $30 \mu \mathrm{g}$; gentamicin, $30 \mu \mathrm{g}$; novobiocin, $5 \mu \mathrm{g}$; tetracycline, $30 \mu \mathrm{g}$; kanamycin, $30 \mu \mathrm{g}$; lincomycin, $15 \mu \mathrm{g}$; oleandomycin, $15 \mu \mathrm{g}$; neomycin, $30 \mu \mathrm{g}$; and carbenicillin, $100 \mu \mathrm{g}$. Assimilation of various substrates and enzyme activity were tested by using the API 20E, API 20NE, API $50 \mathrm{CH}$ and API ZYM systems (bioMérieux). The cells were suspended in AUX medium according to the manufacturer's instructions to inoculate the API 50CH system.

Cell biomass for DNA extraction and for isoprenoid quinone analysis was obtained from cultures grown in trypticase soy broth at $30^{\circ} \mathrm{C}$. Chromosomal DNA was isolated and purified according to the method described by Yoon et al. (1996), with the exception that RNase T1 was used in combination with RNase A to minimize contamination with RNA. The $16 \mathrm{~S}$ rRNA gene was amplified by using a PCR with two universal primers as described previously (Yoon et al., 1998). Sequencing of the amplified 16S rRNA gene and phylogenetic analysis were performed as described by Yoon et al. (2003). Isoprenoid quinones were extracted according to the method of Komagata \& Suzuki (1987) and analysed using reversed-phase HPLC and a YMC ODS-A $(250 \times 4.6 \mathrm{~mm})$ column. For fatty acid methyl ester analysis, cell mass of strain DS- $16^{\mathrm{T}}$ was harvested from TSA plates after incubation for 3 days at $30{ }^{\circ} \mathrm{C}$. The fatty acid methyl esters were extracted and prepared according to the standard protocol of the MIDI/Hewlett Packard Microbial Identification System (Sasser, 1990). The DNA G + C content was determined by using the method of Tamaoka \& Komagata (1984) with the modification that DNA was hydrolysed and the resultant nucleotides were analysed by reversed-phase HPLC. DNA-DNA hybridization was performed fluorometrically by the method of Ezaki et al. (1989) using photobiotin-labelled DNA probes and microdilution wells. Hybridization was performed with five replications for each sample. The highest and lowest values obtained in each sample were excluded and the means of the remaining three values were quoted as DNA-DNA relatedness values.

Morphological, cultural, physiological and biochemical characteristics of strain DS- $16^{\mathrm{T}}$ are given in the species description (see later) or are shown in Table 1 and Supplementary Table S1 in IJSEM Online. The almost complete $16 \mathrm{~S}$ rRNA gene sequence of strain DS- $16^{\mathrm{T}}$ determined in this study comprised $1500 \mathrm{nt}$, representing approximately $96 \%$ of the Escherichia coli $16 \mathrm{~S}$ rRNA gene sequence. In the phylogenetic tree based on the neighbour-joining algorithm, strain DS- $16^{\mathrm{T}}$ joined the clade comprising Stenotrophomonas species at a bootstrap confidence value of $77 \cdot 2 \%$ (Fig. 1). The relationships between strain DS- $16^{\mathrm{T}}$ and Stenotrophomonas species were also recovered in the

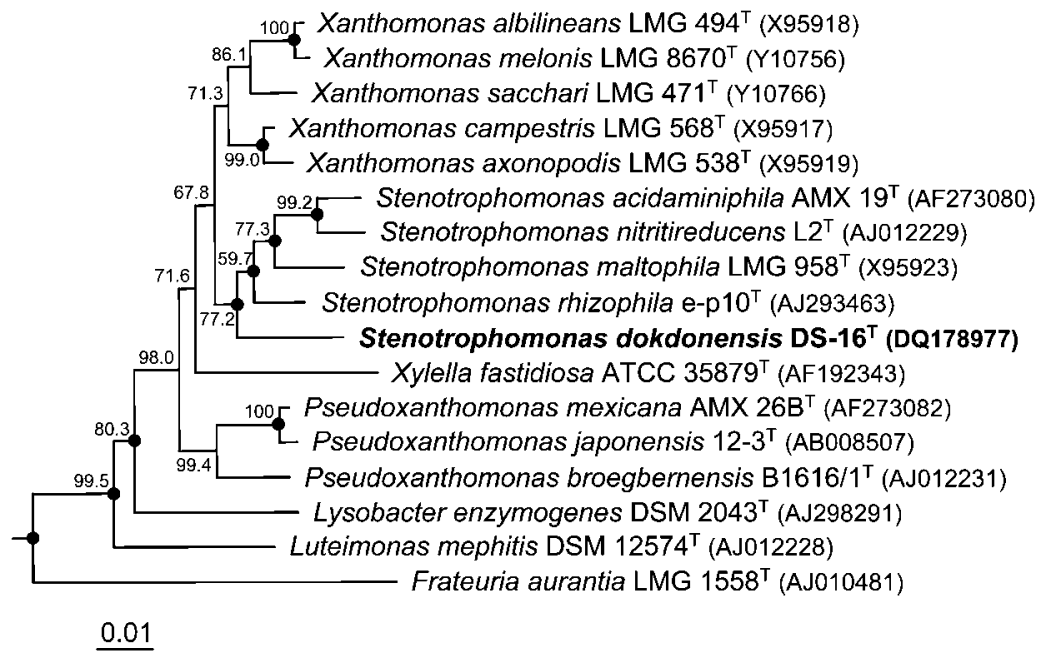

Fig. 1. Neighbour-joining phylogenetic tree, based on 16S rRNA gene sequences, showing the positions of $S$. dokdonensis DS-16 ${ }^{\mathrm{T}}$, other Stenotrophomonas species and some other related taxa. Bootstrap values (expressed as percentages of 1000 replications) above $50 \%$ are shown at branch points. E. coli ATCC $11775^{\top}$ was used as an outgroup. Filled circles indicate that the corresponding nodes were also recovered in the trees generated with the maximum-likelihood and maximum-parsimony algorithms. Bar, 0.01 substitutions per nucleotide position. 
trees based on the maximum-likelihood and maximumparsimony algorithms (Fig. 1). Strain DS- $16^{\mathrm{T}}$ exhibited a $16 \mathrm{~S}$ rRNA gene sequence similarity value of $97 \cdot 5 \%$ with respect to $S$. rhizophila e-p $10^{\mathrm{T}}$ and similarities of $95 \cdot 5-$ $95.9 \%$ to the type strains of the other Stenotrophomonas species. Sequence similarities to all other species included in the phylogenetic analysis were below $97 \cdot 0 \%$ (Fig. 1). The fatty acid profile of strain DS- $16^{\mathrm{T}}$ comprised the following: branched fatty acids iso- $\mathrm{C}_{16: 0}(27 \cdot 6 \%)$, iso- $\mathrm{C}_{15: 0}(19 \cdot 6 \%)$, iso- $\mathrm{C}_{17: 1} \omega 9 c(11.9 \%)$, iso- $\mathrm{C}_{11: 0}(5.6 \%)$, anteiso- $\mathrm{C}_{15: 0}$ $(3 \cdot 4 \%)$, iso- $\mathrm{C}_{17: 0}(3 \cdot 4 \%)$, iso- $\mathrm{C}_{14: 0}(2 \cdot 1 \%)$ and anteiso$\mathrm{C}_{17: 0}(1 \cdot 5 \%)$; hydroxy fatty acids iso- $\mathrm{C}_{11: 0} 3-\mathrm{OH}(4 \cdot 1 \%)$ and iso- $\mathrm{C}_{12: 0} 3-\mathrm{OH}(2 \cdot 8 \%)$; unsaturated fatty acids $\mathrm{C}_{18: 1} \omega 7 c(1.5 \%)$ and $\mathrm{C}_{16: 1} \omega 7 c$ alcohol $(1.0 \%)$; straightchain fatty acid $\mathrm{C}_{16: 0}(1.8 \%)$; and summed feature 3 , comprising $\mathrm{C}_{16: 1} \omega 7 c$ and/or iso- $\mathrm{C}_{15: 0} 2-\mathrm{OH}(7 \cdot 8 \%)$. This fatty acid profile was similar to those of Stenotrophomonas species (Finkmann et al., 2000; Assih et al., 2002; Wolf et al., 2002). The predominant respiratory lipoquinone detected in strain DS- $16^{\mathrm{T}}$ was Q-8, at a peak area ratio of approximately $98 \%$. The DNA G + C content of strain DS $-16^{\mathrm{T}}$ was $65 \cdot 1 \mathrm{~mol} \%$. The mean DNA-DNA relatedness levels between strain DS- $16^{\mathrm{T}}$ and the type strains of the four Stenotrophomonas species were in the range 9-21\%, indicating that these strains represent different genomic species (Wayne et al., 1987). Strain DS- $16^{\mathrm{T}}$ differed from the recognized Stenotrophomonas species in several phenotypic characteristics (Table 1). The phylogenetic distinctiveness and differential phenotypic properties were sufficient to categorize strain DS- $16^{\mathrm{T}}$ as a member of a species that is distinct from previously recognized Stenotrophomonas species (Stackebrandt \& Goebel, 1994). Therefore, on the basis of the data presented, strain DS-16 ${ }^{\mathrm{T}}$ should be placed in the genus Stenotrophomonas as a member of a novel species, for which the name Stenotrophomonas dokdonensis sp. nov. is proposed.

\section{Description of Stenotrophomonas dokdonensis sp. nov.}

Stenotrophomonas dokdonensis (dok.do.nen'sis. N.L. fem. adj. dokdonensis of Dokdo, a Korean island, from where the organism was isolated).

Cells are Gram-negative, non-motile rods $(0 \cdot 2-0 \cdot 4 \times 0 \cdot 7-$ $2 \cdot 6 \mu \mathrm{m})$. Colonies on TSA are circular, convex, sticky, glistening, cream-yellow in colour and $1.5-2.5 \mathrm{~mm}$ in diameter after 3 days incubation at $30^{\circ} \mathrm{C}$. Optimal temperature for growth is $30^{\circ} \mathrm{C}$. Growth occurs at 10 and $40^{\circ} \mathrm{C}$, but not at 4 or $41^{\circ} \mathrm{C}$. Optimal pH for growth is between $6 \cdot 0$ and 7.0; growth occurs at $\mathrm{pH} 5 \cdot 5$ and $8 \cdot 5$, but not at $\mathrm{pH} 5 \cdot 0$ or $9 \cdot 0$. Growth occurs in the presence of $0-6 \%(\mathrm{w} / \mathrm{v}) \mathrm{NaCl}$; optimal growth occurs in the presence of $0.5 \%(\mathrm{w} / \mathrm{v}) \mathrm{NaCl}$. Anaerobic growth does not occur on TSA or on TSA supplemented with nitrate. Catalase-positive. Urease-negative. Tweens 20, 40 and 60 are hydrolysed. $\mathrm{H}_{2} \mathrm{~S}$ and indole are not produced. Arginine dihydrolase, lysine decarboxylase, ornithine decarboxylase and tryptophan deaminase are absent. Susceptible to polymyxin B, chloramphenicol, cephalothin, carbenicillin and oleandomycin, but not to lincomycin. The predominant ubiquinone is Q-8. The major fatty acids ( $>10 \%$ of total fatty acids) are iso- $\mathrm{C}_{16: 0}$, iso- $\mathrm{C}_{15: 0}$ and iso- $\mathrm{C}_{17: 1} \omega 9 c$. The DNA G+C content is $65 \cdot 1 \mathrm{~mol} \%$ (determined by HPLC). Other phenotypic characteristics are given in Table 1.

The type strain, DS- $16^{\mathrm{T}}\left(=\mathrm{KCTC} 12543^{\mathrm{T}}=\mathrm{CIP} 108839^{\mathrm{T}}\right)$, was isolated from soil.

\section{Acknowledgements}

This work was supported by the 21C Frontier Program of Microbial Genomics and Applications (grant MG05-0401-2-0) from the Ministry of Science and Technology (MOST) of the Republic of Korea. We are grateful to the Ulleung County Administration and the Cultural Heritage Administration of the Republic of Korea for facilitating access to Dokdo.

\section{References}

Assih, E. A., Ouattara, A. S., Thierry, S., Cayol, J.-L., Labat, M. \& Macarie, H. (2002). Stenotrophomonas acidaminiphila sp. nov., a strictly aerobic bacterium isolated from an upflow anaerobic sludge blanket (UASB) reactor. Int J Syst Evol Microbiol 52, 559-568.

Cowan, S. T. \& Steel, K. J. (1965). Manual for the Identification of Medical Bacteria. London: Cambridge University Press.

Ezaki, T., Hashimoto, Y. \& Yabuuchi, E. (1989). Fluorometric deoxyribonucleic acid-deoxyribonucleic acid hybridization in microdilution wells as an alternative to membrane filter hybridization in which radioisotopes are used to determine genetic relatedness among bacterial strains. Int J Syst Bacteriol 39, 224-229.

Finkmann, W., Altendorf, K., Stackebrandt, E. \& Lipski, A. (2000). Characterization of $\mathrm{N}_{2} \mathrm{O}$-producing Xanthomonas-like isolates from biofilters as Stenotrophomonas nitritireducens sp. nov., Luteimonas mephitis gen. nov., sp. nov. and Pseudoxanthomonas broegbernensis gen. nov., sp. nov. Int J Syst Evol Microbiol 50, 273-282.

Komagata, K. \& Suzuki, K. (1987). Lipids and cell-wall analysis in bacterial systematics. Methods Microbiol 19, 161-203.

Lanyi, B. (1987). Classical and rapid identification methods for medically important bacteria. Methods Microbiol 19, 1-67.

Palleroni, N. J. (1984). Genus Pseudomonas Migula 1894. In Bergey's Manual of Systematic Bacteriology, vol. 1, pp. 141-199. Edited by N. R. Krieg \& J. G. Holt. Baltimore: Williams \& Wilkins.

Palleroni, N. J. \& Bradbury, J. F. (1993). Stenotrophomonas, a new bacterial genus for Xanthomonas maltophila (Hugh 1980) Swings et al. 1983. Int J Syst Bacteriol 43, 606-609.

Sasser, M. (1990). Identification of Bacteria by Gas Chromatography of Cellular Fatty Acids. Newark, DE: MIDI.

Stackebrandt, E. \& Goebel, B. M. (1994). Taxonomic note: a place for DNA-DNA reassociation and 16S rRNA sequence analysis in the present species definition in bacteriology. Int J Syst Bacteriol 44, 846-849.

Tamaoka, J. \& Komagata, K. (1984). Determination of DNA base composition by reverse-phase high-performance liquid chromatography. FEMS Microbiol Lett 25, 125-128.

Wayne, L. G., Brenner, D. J., Colwell, R. R. \& 9 other authors (1987). International Committee on Systematic Bacteriology. Report of the ad hoc committee on reconciliation of approaches to bacterial systematics. Int J Syst Bacteriol 37, 463-464. 
Wolf, A., Fritze, A., Hagemann, M. \& Berg, G. (2002). Stenotrophomonas rhizophila sp. nov., a novel plant-associated bacterium with antifungal properties. Int J Syst Evol Microbiol 52, 1937-1944.

Yoon, J.-H., Kim, H., Kim, S.-B., Kim, H.-J., Kim, W. Y., Lee, S. T., Goodfellow, M. \& Park, Y.-H. (1996). Identification of Saccharomonospora strains by the use of genomic DNA fragments and rRNA gene probes. Int J Syst Bacteriol 46, 502-505.
Yoon, J.-H., Lee, S. T. \& Park, Y.-H. (1998). Inter- and intraspecific phylogenetic analysis of the genus Nocardioides and related taxa based on 16S rRNA gene sequences. Int J Syst Bacteriol 48, 187-194.

Yoon, J.-H., Kang, K. H. \& Park, Y.-H. (2003). Psychrobacter jeotgali sp. nov., isolated from jeotgal, a traditional Korean fermented seafood. Int J Syst Evol Microbiol 53, 449-454. 